\title{
Biomineralization of Calcium Oxalate Crystals in Leaves of Colocasia esculenta (L.) Schott (Araceae) in Response to Herbivory and Water Regime
}

\author{
Kenneth C. Eco and Beatriz S. Belonias \\ Visayas State University, Visca, Baybay City, Leyte
}

ABSTRACT

Calcium oxalate crystals are common constituents of plant tissues and are believed to play a role in protection against herbivory, calcium regulation and even heavy metal sequestration. In this study, calcium oxalate crystals in leaves of Colocasia esculenta were studied in order to elucidate the biomineralization process of these inorganic components in response to herbivory and different water regimes. Different crystal types occurring in the leaves of $C$. esculenta were identified, described and quantified in terms of density and distribution. Two general types of calcium oxalate crystals were found, namely: the raphides and druses. The raphides were of two types, the defensive and non- defensive, and both occurred as bundles of elongated crystals enclosed in specialized cells called idioblasts. Druses were spherical conglomerate crystals extensively distributed throughout the leaf. Although degree of herbivory did not significantly affect overall density of calcium oxalate crystals, there was a highly significant interaction effect between herbivory and crystal type. With increasing degree of herbivory from $10 \%$ to $30 \%$, the density of druses and non-defensive raphides decreased significantly but that of the defensive type increased. Water availability had a highly significant effect on overall crystal density. Interaction effect between water regime and crystal type was also highly significant. Density of druses significantly increased under waterlogged than non-waterlogged conditions while those of the defensive and non-defensive raphides were unaffected.

Keywords: defensive raphides, non- defensive raphides druses, crystal density, idioblasts

\section{INTRODUCTION}

Calcium oxalate ( $\mathrm{CaOx}$ ) crystals are the most common and widely distributed biomineral in plants. It is an insoluble mineral formed from calcium (Ca) derived from the environment and oxalic acid (2-carbon dicarboxylic acid) synthesized within the plant. (Chairiyah et al 2013).

Correspondence: Beatriz S. Belonias Address: Department of Biological Science,Visayas State University, Baybay City, Leyte Philippines 6521-A E-mail: beatrizbelonias@vsu.edu.ph DOI: $10.32945 /$ atr3914.2017 
These crystals normally form intracellularly, but extracellular crystals have also been reported (Prychid \& Rudall 1999). They are believed to provide protection of plants against herbivores, and are also believed to play a role in calcium regulation and heavy metal sequestration (Franceschi \& Nakata 2005, Nakata 2003).

Based on morphology, $\mathrm{CaOx}$ crystals are classified as raphides, styloids, druses, prisms and crystal sands. However, in the aroid family (Araceae), raphides and druses are the most common types. Raphides are bundles of elongated crystals that are needle- like and druses are spherical conglomerates of multiple crystals with many pointed tips. Members of this family often possess highly unusual grooved raphide crystals which are almost distinct to the taxon with the exception of Tragia sp. of the family Euphorbiaceae. (source) Both raphides and druses are often concentrated in the mesophyll tissues of the leaves although occurrences of other types are also possible (Prychid et al 2008).

Crystals are found in different plant parts such as in stem pith cell and petal cells of Aster squamatus (Araceae) and ovary of Bellis perennis (Meric 2009); in corms and leaves of Colocasia esculenta (Saadi \& Mondal 2011); leaves of rice, Sida sp. and mulberry (Shibata et al 1981, Flores 2001, Nagaoka et al 2010); leaves and inflorescences of Dieffenbachia sp. (Cao 2003); cuticles of Dracaena sp. (Pennisi \& McConnel 2001); in phyllodes and branchlets of Acacia robeorum (He et al 2012); in developing seeds of soybean (Ilarslan et al 2001) and in tubers of sweet potato (Ipomoea batatas) and Japanese Yam (Dioscorea japonica) (Schadel \& Walter 1980, Kawasaki et al 2004). These crystals are considered to be part of the cell as cell inclusions. They occur either inside the cell vacuole or in the extracellular matrix of various plant tissues. The production of these crystals is a normal physiological phenomenon in plants. The crystalline form can even make up about $1 \%$ to $90 \%$ of the plant's dry matter (Nakata 2003). Various studies (Prychid \& Rudall 1999, Tuason \& Arecona 2009, Cao 2003), have shown that environmental conditions such as seasonal changes and soil water content may influence crystal formation. In fact, Franceschi (1989) as cited by Sugimura et al (1999), said that CaOx levels can be increased or decreased in response to changes in $\mathrm{Ca}+$ content of the growth medium.

Kumoro et al (2014) mentioned that most Colocasia or taro cultivars taste acrid and can cause irritation to the skin, lips, mouth and throat if eaten raw or upon contact with the plant parts (Mare 2009). Although CaOx crystals in taro have already been described by Saadi and Mondal (2011) and Osuji (2013), the effect of herbivory and water availability on crystal formation in this species has not been studied. Knowledge of the conditions that may induce or reduce crystal formation can also help growers in the management of their taro farms with the aim of producing good- quality plants having reduced acrid taste and are less irritating to the skin. 
In this study, the effects of herbivory and water regime on CaOx crystal production and distribution in the leaves of Colocasia esculenta (L.) Schott were evaluated in order to elucidate the possible role of these crystals in the plant. Taro was used in this experiment due to its importance as global food source, its natural susceptibility to attack of herbivores such as the taro hornworm and aphids (Carmichael et al 2008) as well as its ability to grow in both waterlogged and non- waterlogged conditions.

\section{MATERIALS AND METHODS}

\section{Preparation and Care of Experimental Plants}

Planting materials of gabi or taro var. Kalpao were obtained from the Philippine Rootcrops Research and Training Center (PhilRootcrops) of the Visayas State University. Suckers of more or less the same size and age were planted in pots containing approximately $2 \mathrm{~kg}$ of ordinary garden soil. Plants were maintained in the screenhouse and allowed to grow until the two-to-three leaf stage. Watering of samples was done daily unless specified otherwise according to the treatment used.

Experimental Design and Treatments

There were two experiments conducted. The first experiment investigated the effect of herbivory while the second assessed the effect of different water regimes on $\mathrm{CaOx}$ density and distribution. Each experiment was arranged in a 3-factor factorial in Completely Randomized Design (CRD). Each treatment was replicated thrice giving a total of 21 experimental pots with two sample plants per pot.

\section{Experiment 1. Effect of Herbivory}

Herbivory was simulated by cutting out a triangular section at the right- hand side of a fully developed leaf blade without damaging the central vein and leaving the left hand side as intact as possible for data collection (Fig. 1). The following were the treatments: $\mathrm{T}_{0}-$ Intact/ Uncut leaf, $\mathrm{T}_{1}-10 \%$ of total leaf area removed, $\mathrm{T}_{2}-20 \%$ of total leaf area removed, and $\mathrm{T}_{3}-30 \%$ of total leaf area removed.

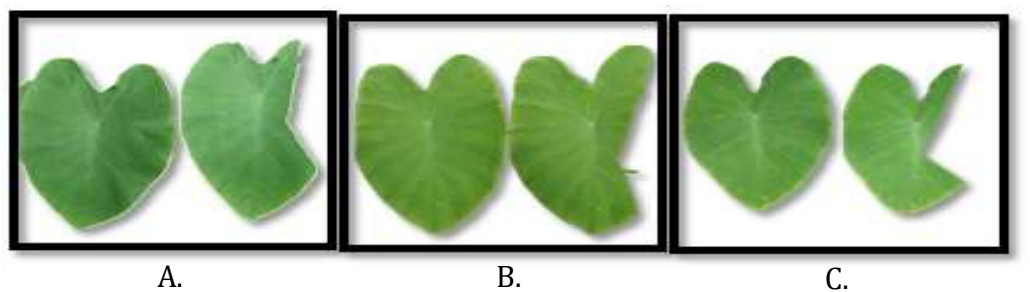

Figure 1. Leaves showing the simulated herbivory treatments. A. $10 \%$ of total leaf area removed; B. $20 \%$ of total leaf area removed; and C. $30 \%$ of total leaf area removed. Intact leaves are the control samples 
Experiment 2. Effect of Different Water Regimes

For the control, water was supplied daily and maintained at field capacity. Waterlogged conditions was carried out by concreting the drainage hole at the base of the pot to prevent water from dripping and maintaining water at saturation. For treatment 1 , water was applied daily and for treatment 3 , every two weeks. The treatments were: $\mathrm{T}_{0}-$ Waterlogged, $\mathrm{T}_{1}$ - Watered daily, and $\mathrm{T}_{2}$ - Watered every two weeks.

\section{Collection of Leaf Samples}

At the termination of the experiment, leaf samples were collected from each treatment. In the herbivory experiment, two sets of leaf samples were taken one week after the imposition of the treatments. Ten circular discs were obtained using an ordinary paper puncher from the leaf margin, the area between the margin and the midvein and near the midvein (Fig. 2A). For the water regime experiment, 10 leaf discs were punched separately on the same three locations of the leaf (Fig. 2B). The samples were stored overnight in test tubes containing $30 \mathrm{~mL} 5 \% \mathrm{NaOH}$.

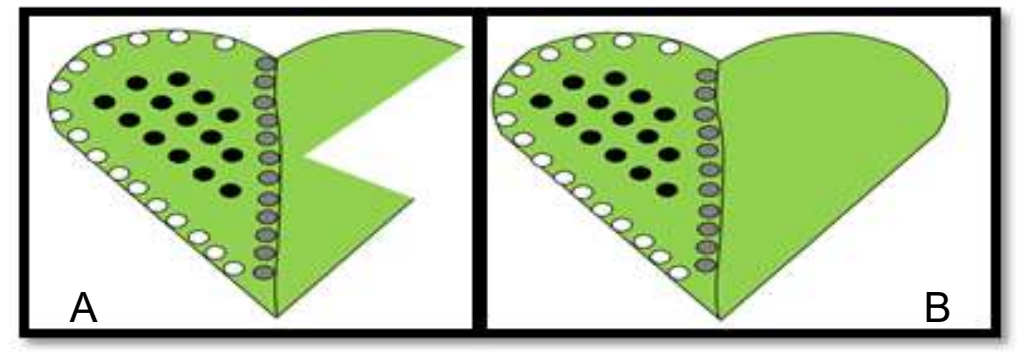

Figure 2. Schematic diagram of the method of leaf disc collection for the herbivory experiment (A) and water availability experiment (B). Leaf discs were collected from the margin $(\bigcirc)$, between the margin and the midvein $(O)$ and near the midvein $(\mathrm{O})$

\section{Clearing of Leaf Samples for Microscopy}

Leaf discs collected were subjected to clearing technique to facilitate crystal counting. Clearing method was based on Coté (2009), with modifications.

From the $5 \% \mathrm{NaOH}$, the samples were transferred to commercial household bleach (Sodium Hypochlorite) for 5 - 10 min and then washed three times in $30 \mathrm{~mL}$ distilled water for at least 10 min each time. For confirmation of the chemical components of the crystals, the cleared samples were treated with $5 \%$ acetic acid for 24 hours. The solution dissolves calcium carbonate and phosphate but not oxalate (Coté 2009). The samples were re-washed three times with distilled water for at least 15 
min each time. Cleared samples were then passed through a dehydration series by passing them through 10\%, 30\%, 50\%, 75\%, 85\% and 95\% reagent grade ethanol, and rinsing in Ter- Butyl Alcohol for at least $10 \mathrm{~min}$ with shaking. Finally, the samples were placed in xylene for 10 min with occasional swirling.

\section{Microscopy and Determination of Crystal Density}

Cleared samples were mounted on glass slides with Canada Balsam and viewed on a bright field microscope. Number of crystals per leaf disk was counted via a cell counter plugged-in linked to ImageJ Software. Photos of the crystals were obtained using a Sony Cybershot DSC-TX10 Digital Still Camera (16.2 megapixels).

\section{Statistical Analyses}

Analysis of Variance (ANOVA) was run to determine significant effects of the treatments. Mean comparison was done using Tukey's Highly Significant Difference (HSD) Test. All analyses were carried out using the MSTAT statistical package.

\section{RESULTS AND DISCUSSION}

\section{Types of Calcium Oxalate Crystals}

Two types of calcium oxalate crystals, namely raphides and druses were observed in the leaves of Colocasia esculenta var. Kalpao. (Fig. 3). This finding corroborates with the studies of Saadi and Mondal (2011), Osuji (2013), Genua and Hillson (1985), Sunell and Healey (1985), and Franceschi and Nakata (2005).

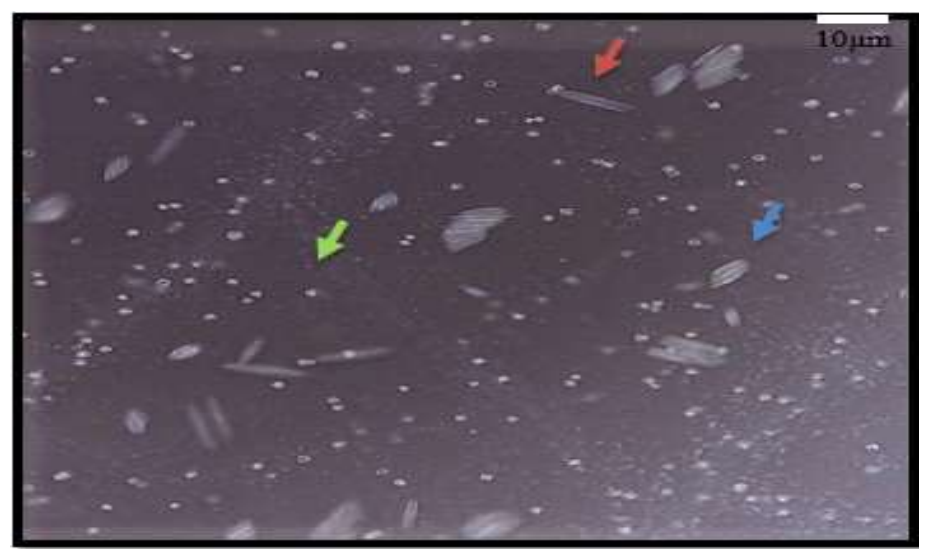

Figure 3. Three crystal types in leaves of Colocasia esculenta showing their individual size, morphology and distribution at $100 \mathrm{x}$ total magnification. Each arrowhead
points to one crystal type: Defensive raphide (orange), non- defensive raphide 
Raphides in C. esculenta occur as bundles of spindle- shaped; needlelike crystals enclosed in a specialized chamber and occurs only in the spongy mesophyll layer of the leaf (Genua \& Hillson 1985). Two types of raphides, the defensive and non-defensive, were also observed in the leaf samples which differed in morphology. The defensive raphides were generally longer $(24-30 \mu \mathrm{m})$ and have distinct terminal papillae at one end and a thin-walled part on the other end (Fig. 4A-B). These crystals are the most common form of crystal in the Araceae family and consist of foursided single crystal having two symmetrical pointed ends (Saadi \& Mondal 2011). These types of raphides are found suspended between mesophyll cells in the leaf air spaces (Sunnel \& Healey 1985). The non- defensive raphides (Fig.4C-D), on the other hand, were shorter $(12-15 \mu \mathrm{m})$ but wider than the defensive type. These raphides are contained in elongated cells that are embedded along the leaf margin (Sunell \& Healey 1985). Both types are enclosed in specialized cells known as idioblasts.

Druses are multifaceted conglomerate crystals found to be more abundant than the raphides but are smaller (Fig.4E-F). They are smaller in diameter $(3-5 \mu \mathrm{m})$, roughly spherical and are scattered all throughout the leaf either as individual crystal or as multiples in cells (Franceschi \& Nakata 2005). They have a more common occurrence than the raphides as they were present in all leaf samples viewed although their density varied between leaf samples.

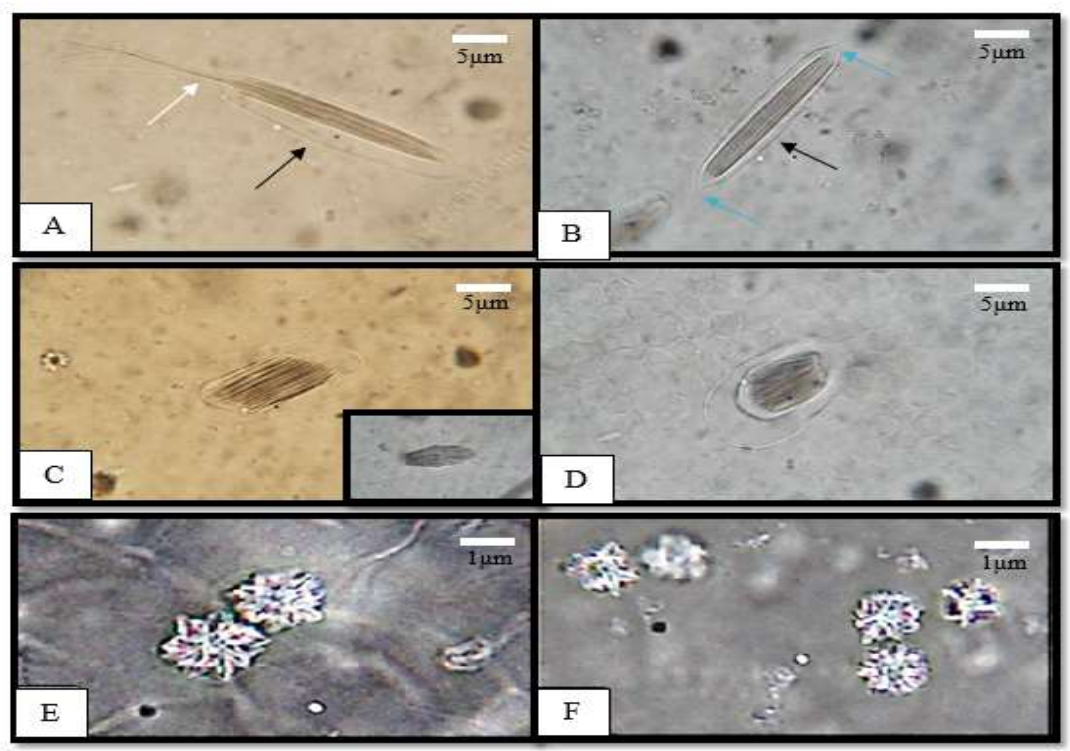

Figure 4. Types of $\mathrm{CaO}$ x crystals in leaves of Colocasia esculenta: A-B. Defensive raphides within an idioblast (black arrow), with distinct terminal papillae (white arrow) and a thin- walled terminal end (blue arrow), C. Non- defensive raphide enclosed in idioblast (inset: non- defensive crystal with different morphology), D. A developing non- defensive raphide in an idioblast, E-F. Groups of druse crystals showing their conglomerate and angular shape. Total magnification: 400x 


\section{Calcium Oxalate Crystal Density in Response to Herbivory}

There was no significant effect of herbivory on the density of calcium oxalate crystals in the leaves of taro, although numerically, the density of raphide crystals increased with increasing degree of herbivory. However, the type of crystals formed was significantly affected by the treatments. Table 1 shows the mean density of crystals per centimeter square $\left(\mathrm{cm}^{2}\right)$ leaf area. Results show that in all treatments, the density of druses was highly significantly higher than both defensive and non-defensive raphides. The druses were the most abundant type of crystal whose density was more than 80 to 135 -fold higher than either type of raphides. The high druse density in the leaf can be related to their smaller size and their possible function as light disperser in photosynthesis (Horner 2012). Their location below the epidermal layer and near the mesophyll tissues further supports this function (Franceschi \& Nakata 2005).

There was a significant interaction effect between degree of herbivory and crystal type (Table 1). When the degree of herbivory was increased from 10 to $30 \%$, the density of defensive raphide crystals also increased from 96.17 crystal idioblasts $/ \mathrm{cm}^{2}$ in the intact leaf to 413.97 crystals idioblasts $/ \mathrm{cm}^{2}$ when $30 \%$ of the total leaf area was removed from the leaf. This translates to about $40 \%, 70 \%$ and $77 \%$ increase in crystal density when $10 \%, 20 \%$ and $30 \%$ herbivory was imposed, respectively.

For the non- defensive raphides, crystal density decreased with increasing herbivory. When $10 \%$ of the leaf area was removed, a $67 \%$ reduction in density area was observed relative to the control, the highest reduction among the treatments.

Table 1. Mean crystal count per $1 \mathrm{~cm}^{2}$ leaf area of Colocasia esculenta in response to herbivory

\begin{tabular}{|l|c|c|c|c|}
\hline \multicolumn{1}{|c|}{ Treatments } & \multicolumn{2}{|c|}{ Raphides } & Degree of \\
& \multicolumn{2}{|c|}{ (crystal idioblasts/cm2) } & Druses & $\begin{array}{c}\text { Herbivory } \\
x\end{array}$ \\
\cline { 2 - 3 } & Defensive & Non- defensive & $\begin{array}{c}\text { (crystals } \\
/ \mathrm{cm} 2)\end{array}$ & $\begin{array}{c}\text { Crystal } \\
\text { type }\end{array}$ \\
\hline 10\% leaf area removed & 96.17 & 85.55 & $13130.00^{\mathrm{a}}$ & \\
20\% leaf area removed & 160.45 & 28.03 & $13530.00^{\mathrm{a}}$ & \\
30\% leaf area removed & 316.23 & 47.57 & $8313.00^{\mathrm{b}}$ & \\
\hline ANOVA & 413.97 & 79.03 & $10500.00^{\mathrm{ab}}$ & \\
\hline
\end{tabular}

ns-non-significant; **- highly significant

Means within a row or column having the same letter are not significantly different at $\alpha=0.05$ 
When herbivory was increased to 20 to $30 \%$, a $44 \%$ and $7.7 \%$ reduction in the mean crystal density was observed, respectively.

For the druses, crystal densities were very high $(13,130-13,530$ crystal idioblasts $/ \mathrm{cm}^{2}$ ) in the intact leaf and in those with $10 \%$ of leaf area removed $\left(13,530\right.$ crystal idioblasts $\left./ \mathrm{cm}^{2}\right)$. However, when herbivory was increased to $20 \%$, a significant reduction was observed which could suggest that a cost and effect relationship between these crystal types is possible considering that evidences have been documented supporting that the process of calcium oxalate crystal formation is a reversible process (Mazen et al 2003, Webb 1999). With increasing herbivory, the plant needs to increase defensive raphide density such that reduction in both nondefensive and druse crystal was observed in order to provide necessary materials for reformation. This further tells us that crystal density is an inducible mechanism in plants and that the presence of non- defensive raphides and druses could play a passive mechanical role in defense aside from the direct role of the defensive raphides against herbivory damage (Franceschi \& Nakata 2005).

The study of Molano (2001) found an increase in calcium oxalate crystal density upon exposure of Sida sp. to artificial herbivory. This could mean that crystal production in mature leaves exposed to increasing herbivory damage increases as a response to the stress and is a strategy of the plant to deter herbivores and prevent further damage. In a study wherein plants subjected to herbivory by natural herbivores, the gazelles, Ward et al (1997) as cited by Molano (2001), found higher number of crystals in the grazed plants compared to the non- grazed plants. Also, mutants of Medicago truncatula which are calcium- oxalate defective have been found to be more preferably grazed by the larvae of beet armyworm (Spodoptera exigua Hubner) compared to the wild type suggesting the role of calcium oxalate crystals as an effective defense against chewing insects. Other studies also showed similar results and showed that crystals, particularly raphides, act as a defense against damage by herbivores (Sunnel \& Healey 1975 \& Ward et al 1997 as cited by Molano 2001). This function of defensive raphides is also related to its morphology wherein it has needle- like pointed structure with a distinct terminal papillae and an idioblast with a thin- walled end that is pressurized and easily ruptures by contact resulting to the ejection of the crystals (Franceschi \& Nakata 2005). However, in other studies such as in Pancratium sickenbergeri and Mulberry (Morus alba) (Ruiz et al 2002 \& Nagaoka et al 2010) no significant effects of herbivory on calcium oxalate crystal density were found.

In relation to the acrid property associated with taro, herbivory could possibly affect the itchy characteristics of the leaves. The defensive raphides plays the primary role in this property with taro such that with 
increasing herbivory, only the defensive raphides increased in density among the two crystal types, although not significant. The reduction in the druse and non- defensive raphide density could mean a compensation mechanism for the formation of defensive raphides, therefore, affecting the quality of taro. This could also mean an inducible mechanism of defensive raphide accumulation in taro leaves.

\section{CaOx Crystal Distribution in Leaves of Colocasia esculenta}

There was no significant difference in the density of the three crystal types in the three leaf regions (Table 2). Density of defensive, nondefensive raphides and druses in the three different leaf locations or regions were not significantly different suggesting a more or less uniform distribution of these crystals throughout the lamina, although numerically, the non-defensive raphides seemed to be more concentrated along the leaf margins. Sunnel and Healey (1985) reported that non-defensive raphides of Colocasia were mostly found along the leaf margins. In this study, druses had the highest mean counts on the area between the margin and the midvein that is, on the largest part of the blade, suggesting its role as light disperser for more efficient photosynthesis as proposed by Horner (2012).

Table 2. Mean crystal count per $1 \mathrm{~cm}^{2}$ leaf area in different regions of the leaves of

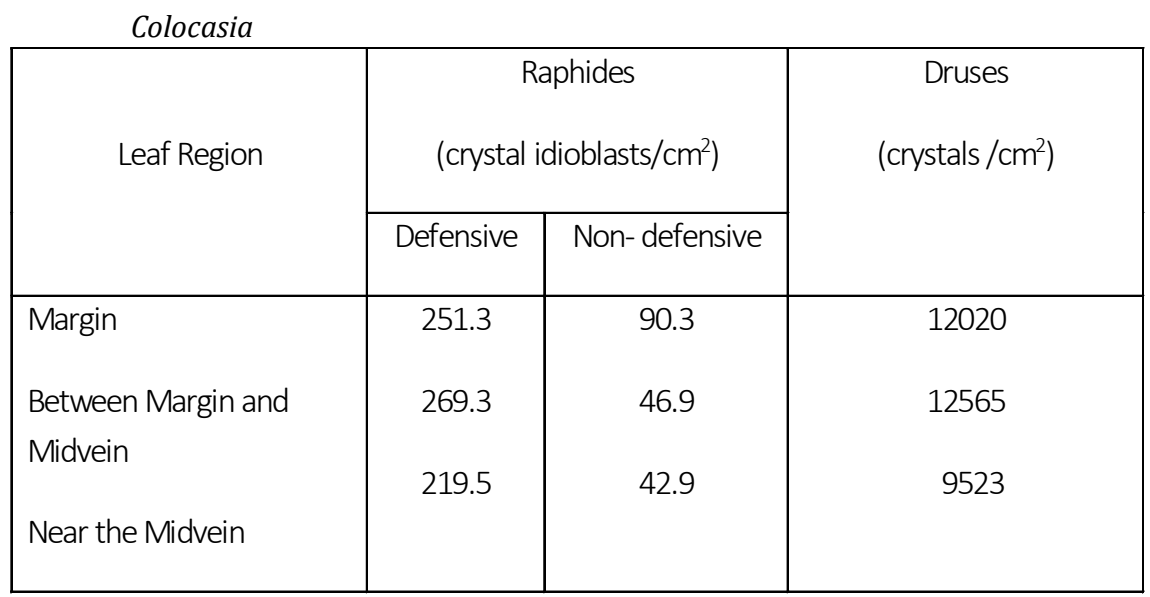

\section{Calcium Oxalate Crystal Density in Response to Different Water Regimes}

With decreasing water content in the soil solution, overall crystal density decreased (Table 3). Although this was observed for all crystal 
types, significant differences were only observed in the mean counts for druse crystals. This could imply that accumulation of druse crystals and its occurrence in the leaf is highly affected by soil water content, delineating its possible role as calcium sink for excess calcium in the leaf (Prychid \& Rudall 1999, Franceschi \& Nakata 2005).

Overall interaction effect between water regime and crystal type was highly significant. Defensive raphides decreased in mean density by $21 \%$ at $20 \%$ herbivory, that is, with little water supplied to the plant. Similarly, non- defensive raphides also decreased in mean density relative to the control by $68 \%$. Significantly, druse crystal density was affected by the treatment with the highest reduction of $40 \%$ obtained when water was applied every two weeks only.

Table 3. Mean crystal count per $1 \mathrm{~cm}^{2}$ leaf area of Colocasia esculenta in response to different water regimes

\begin{tabular}{|c|c|c|c|c|}
\hline \multirow[t]{2}{*}{ Treatments } & \multicolumn{2}{|c|}{$\begin{array}{c}\text { Raphides } \\
\text { (crystal idioblasts/mm2) }\end{array}$} & \multirow[t]{2}{*}{$\begin{array}{c}\text { Druses } \\
\text { (crystals/mm2) }\end{array}$} & \multirow{2}{*}{$\begin{array}{c}\text { Water Regime } \\
\text { x } \\
\text { Crystal Type }\end{array}$} \\
\hline & Defensive & Non- defensive & & \\
\hline Waterlogged & 560.67 & 295.59 & $30132.22^{\mathrm{a}}$ & \\
\hline Watered daily & 513.29 & 139.22 & $16622.22^{b}$ & \\
\hline Watered every 2 weeks & 443.30 & 118.86 & $18183.33^{b}$ & \\
\hline ANOVA & ns & ns & $* *$ & $* *$ \\
\hline
\end{tabular}

Most taro cultivars, such as "Kalpao" variety, grow and are cultivated in waterlogged conditions (Mare 2009, Ahmed 2014). In plants, water plays a significant role in the translocation of calcium from the soil medium to the plant body. In all cases, crystals are formed from environmentally derived calcium (Nakata 2003). Calcium translocation is directly linked to the transpiration stream, via the xylem, following the apoplastic pathway as calcium is highly soluble in water (Gilliham et al 2011). The root hydraulic conductivity also plays a major role in the transport of this macronutrient to the plant such that soil water shortages decreases root hydraulic conductivity and affect calcium uptake and movement through the plant (Wu et al 2012). At waterlogging conditions given the uncontrolled 
environmental conditions of the modified screenhouse, transpiration stream could be high such that water evapotranspiration increases in the leaf which could result to the accumulation of high calcium in the plant. Excess calcium in a plant has detrimental effects on the plant system as this affects crucial cellular processes like calcium- dependent signaling and microskeletal dynamics (Webb 1999). Since plants accumulate calcium in excess of cytosolic limits and they do not have well- developed excretory systems to eliminate excess calcium, compartmentalization of the element via accumulation of calcium oxalate crystals in specialized cells is one mechanism of sequestration (Webb 1999). Druse crystals could possibly play this role for taro since the highest density which was significantly different with the other treatments was obtained at waterlogged conditions. Furthermore, at limited soil water, that is, at treatment three, lowest density was obtained which could support the relationship between calcium translocation in plants with water availability (Ahmed et al 2012). Numerically, both the two types of raphides also has highest density in waterlogged conditions and lowest at the third treatment which could suggest their possible role in calcium sequestration. In contrary, age of leaves and water content did affect calcium oxalate crystal formation in three different plant leaves (Ficus religiosa, Heterophragma adenophyllum and Spinacia oleracea) subjected to carbonate treatments (Ahmed et al 2012). In this study, the role of water content significantly affected $\mathrm{CaOx}$ crystal formation and is dependent on the age of leaves. Mature leaves with lowest water content accumulated the highest calcium oxalate crystals which implied that water plays a very significant role in stabilizing calcium oxalate in the leaves given that the amount of oxalate is also inversely proportional to the amount of water in the organ. The difference between the results of this study could be due to the difference on the set- up used. In this experiment, actual contact between the plants and the natural environment, the soil medium, was established which could have elucidated the more natural interaction of the plant to the soil while in the other study, leaves were removed from the mother plant and then were subjected to the treatments which could have yielded a different result given that the water content of the leaves could have varied through time.

In relation to the acrid property associated with taro, results of this study revealed that under waterlogged conditions, calcium oxalate crystals tend to increase and accumulate in the leaves which could suggest a more acrid property for cultivars planted and grown under such water regime. Although acridity in most taro cultivars is an inherent property of the variety, this study showed that crystal density could be induced when taro was grown when water is abundantly supplied such as in waterlogged 
conditions. Proper management practices to reduce the excessive formation and accumulation of these crystals in the plant could be done such as prevention of over-irrigation.

\section{Crystal Distribution in Leaves of Colocasia esculenta}

Distribution of calcium oxalate crystals in different locations of the leaf lamina was not significantly affected by soil water availability (Table 4). There was no significant difference between mean densities of crystals in the three leaf regions consistent with the result of the herbivory experiment.

Table 4. Mean crystal count per $1 \mathrm{~cm}^{2}$ leaf area in different regions of the leaves of Colocasia esculenta

\begin{tabular}{|l|c|c|c|}
\hline \multirow{2}{*}{ Leaf Region } & \multicolumn{2}{|c|}{ Raphides } & \multirow{2}{*}{ Druses } \\
\cline { 2 - 3 } & Defensive & Non- defensive & (crystals $/ \mathrm{cm}^{2}$ ) \\
\cline { 2 - 3 } Margin & 531.61 & 200.79 & 22332.22 \\
Between Margin and Midvein & 537.16 & 178.38 & 23786.67 \\
Near the Midvein & 448.49 & 174.49 & 18818.89 \\
\hline
\end{tabular}

\section{CONCLUSION}

Raphides (defensive and non-defensive types) and druses were observed in C. esculenta var. Kalpao. Artificial herbivory did not affect the density of $\mathrm{CaOx}$ crystals. However, there was a significant interaction between degree of herbivory and crystal type. Density of defensive raphides increased with increasing degree of herbivory while density of non- defensive raphides and the druses decreased with increasing degree of herbivory suggesting a possible interconversion between these crystal types. There was no significant interaction found between leaf region and the crystal type suggesting a more or less uniform distribution of crystals in the lamina especially for the defensive raphides and the druses. Soil water content significantly increased the density of druse crystals while those of the raphides were unaffected.

Results of this experiment revealed that acridity in taro, which has been reported to be due to the presence of CaOx crystals, could possibly bereduced by managing soil water availability and insect pest infestation. 


\section{LITERATURE CITED}

AHMED, I. 2014. Evolutionary Dynamics in Taro (Colocasia esculenta (L.) Schott). PhD Thesis. Massey University, Palmerston North, New Zealand.

CAO, H. 2003. The Distribution of Calcium Oxalate Crystals in Genus Dieffenbachia Schott and the Relationship Between Environmental Factors and Crystal Quantity and Quality. Master's Thesis. University of Florida

CARMICHAEL A., R. HARDING, G. JACKSON, S. KUMAR, S. LAL, R. MASAMDU, J. WRIGHT and A. CLARKE. 2008. Taro pest: An illustrated guide to pests and diseases of taro in South Pacific. ACIAR Monograph No. 132, 76 pp.

COTE, G.C. 2009. Diversity and distribution of idioblasts producing calcium oxalate crystals in Dieffenbachia seguine (Araceae). American Journal of Botany 96 (7): 1245-1254

FLORES, B.M. 2001. Herbivory and calcium concentrations affect calcium oxalate crystal formation in leaves of Sida (Malvaceae). Annals of Botany 94: 377-384

FRANCESCHI, V.R. and P.A. NAKATA. 2005. Calcium oxalate in plants: Formation and function. Annual Review of Plant Biology 56: 41-71

GENUA, J.M. and C.J. HILLSON. 1985. The occurrence, type and location of calcium oxalate crystals in the leaves of fourteen species of Araceae. Annals of Botany 56: 351-361

GILLIHAM, M., M. DAYOD, B.J. HOCKING, B. XU, S.J. CONN, B.N. KAISER, R.A.

LEIGH and S. D. TYERMAN. 2011. Calcium delivery and storage in plant leaves: exploring the link with water flow. Journal of Experimental Botany 62 (7): 2233-2250

HORNER, H.T. 2012. Peperomia leaf cell wall interface between the multiple hypodermis and crystal-containing photosynthetic layer displays unusual pit fields. Annals of Botany 109: 1307-1315

ILARSLAN, H., R.G. PALMER and H.T. HORNER. 2001. Calcium oxalate crystals in developing seeds of soybean. Annals of Botany 88: 243- 257

KAWASAKI, M., M. TANIGUCHI and H. MIYAKE. 2004. Structural changes and fate of crystalloplastids during growth of calcium oxalate crystal idioblasts in Japanese Yam (Dioscorea japonica Thunb.) Tubers. Plant Production Science 7 (3): 283- 291

KUMORO, A.C. 2012. Development of efficient calcium oxalate removal techniques from Taro corms. Prosiding SNST ke-3 Tahun 2012. Fakultas Teknik Universitas Wahid Hasyim Semarang

KUMORO, A.C., C.S. BUDIYATI and D.S. RETNOWATI. 2014. Calcium oxalate reduction during soaking of giant taro (Alocasia macrorrhiza (L.) Schott) corm chips in sodium bicarbonate solution. International Food Research Journal 21 (4): 1583-1588 
MARE, R. 2009. Taro (Colocasia esculenta (L.) Schott) Yield and Quality Response to Planting Date and Organic Fertilization. PhD Thesis. University of KwaZulu-Natal

MERIC, C. 2009. Calcium oxalate crystals in Aster squamatus and Bellis perennis (Asteraceae: Astereae). Phytologia Balcanica 15 (2): 255-259

NAKATA, P.A. 2003. Advances in our understanding of calcium oxalate crystal formation and function in plants. Plant Science 164 (6): 901909

NAGAOKA, S., H. KATAYAMA, Y. FUJIBAYASHI and Y. SUGIMURA. 2010. Calcium oxalate crystals in Mulberry leaves: No negative effect on feeding silkworm, Bombyx mori. Journal of Insect Biotechnology and Sericology 79: 71-74

OSUJI, J.0. 2013. Probable functions of calcium oxalate crystals in different tissues of the edible aroids (Xanthosoma and Colocasia spp.) in Nigeria. African Journal of Biotechnology 12 (25): 3952-3956

PENNISI, S.V. and D.B. McCONNEL. 2001. Taxonomic relevance of calcium oxalate cuticular deposits in Dracaena Vand. ex L. Hortscience 36 (6):1033-1036

PRYCHID, C.J. and P. RUDALL. 1999. Calcium oxalate crystals in monocotyledons: A review of their structure and systematics. Annals of Botany 84: 725-739

PRYCHID, C.J., R.S. JABAILY and P.J. RUDALL. 2008. Cellular ultrastructure and crystal development in Amorphophallus (Araceae). Annals of Botany 101: 983-995

RUIZ, N., D.WARD and D. SALTZ. 2002. Calcium oxalate crystals in leaves of Pancratium sickenbergeri: constitutive or induced defence?. Functional Ecology 16: 99-105

SAADI, A.I. and A.K. MUNDAL. 2011. Studies on the calcium oxalate crystals of some selected aroids (Araceae) in Eastern India. Advances in Bioresearch 2(1): $134-143$

SCHADEL, W.E. and W.M. WALTER JR. 1980. Calcium oxalate crystals in the roots of Sweet Potato. Journal of the American Society for Horticultural Science 105 (6): 851-854

SHIBATA, S. K. SATO and K. HOSHIKAWA. 1981. On the calcium oxalate crystals on rice leaves. Japan Journal of Crop Science 50 (2): 210-216

SUGIMURA, Y., T. MORI, I. NITTA, E. KOTANI, T. FURUSAWA, M. TATSUMI, S. KUSAKARI, M. WADA and Y. MORITA. 1999. Calcium deposition in idioblasts of Mulberry leaves. Annals of Botany 83: 543-550

SUNELL, L.A. and P.L. HEALEY. 1985. Distribution of calcium oxalate crystal idioblasts in leaves of Taro (Colocasia esculenta (L.) Schott). American Journal of Botany. 72 (12): $1854-1860$

TUASON, M.M.S and J.M. ARECONA. 2009. Calcium oxalate biomineralization by Piloderma fallax in response to various levels of Calcium and Phosphorus. Applied and Environmental Microbiology 75 (22): 7079-7085 
WEBB, M.A.. 1999. Cell mediated crystallization of calcium oxalate in plants. The Plant Cell 11: 751-761

WU, Y., X. LIU, W. WANG, S. ZHANG and B. XU. 2012. Calcium regulates the cell- to-cell water flow pathway in maize roots during variable water conditions. Plant Physiology and Biochemistry 53: 212-219 